\title{
Коллекция генетических ресурсов льна Всероссийского института генетических ресурсов растений им. Н.И. Вавилова
}

\author{
Е.А. Пороховинова (D), С.Н. Кутузова (D), А.В. Павлов (D), А.А. Слободкина (D), Т.В. Якушева (D), Н.Б. Брач (D)凶
}

\begin{abstract}
Аннотация: Сохранение генетических ресурсов культурных растений (ГРР) в основном осуществляют ех situ. Наибольшее количество образцов льна в мире (6243) хранится во Всероссийском институте генетических ресурсов растений им. Н.И. Вавилова (ВИР). Коллекция ГРР льна ВИР официально берет начало в 1922 г. В ней собраны льны со всех континентов кроме Антарктиды: больше всего образцов из Европы (1946) и Азии (1695), России (1696); меньше - из Северной (301) и Южной (248) Америк, Африки (220), Австралии и Океании (64). Всего в коллекции представлено разнообразие льна 83 стран мира. Десять процентов коллекции составляют местные формы, 40\% - образцы народной селекции, 24\% приходится на селекционный материал и 25\% - на проработанные сорта и линии, менее $1 \%$ коллекции занимают дикие виды льна. Уникальность коллекции льна ВИР заключается в более 1900 образцов, собранных в 55 странах мира в результате более 120 экспедиций ВИР. Создание и пополнение коллекции можно разделить на пять этапов, связанных с историческими событиями. Каждый из них характеризуется особенностями привлекаемого материала. Все образцы льна перед поступлением в коллекцию проходят комплексное изучение по основным морфологическим и хозяйственно ценным признакам. Дополнительное изучение частей коллекции направлено на определение принципов создания и структурирования коллекции, оценку влияния условий среды на развитие льна, определение разными методами качества волокна, изучение биохимического состава семян и генетического контроля признаков льна. Сохранение генетических ресурсов в меняющемся мире - одна из первостепенных задач, стоящих перед всеми государствами. Специалисты ВИР вносят неоценимый вклад в решение этого вопроса.
\end{abstract}

Ключевые слова: Linum usitatissimum; лен; коллекция генетических ресурсов растений; генный банк; образцы коллекции; местные образцы; сорта; географическое происхождение.

Благодарности: Работа выполнена в рамках государственного задания согласно тематическому плану ВИР по проекту № 06622019-0001 «Коллекция масличных и прядильных культур ВИР: поддержание, изучение, расширение генетического разнообразия», номер государственной регистрации АААА-А19-119013090159-5. Авторы благодарят д-ра биол. наук В.А. Гаврилову, куратора коллекции подсолнечника ВИР, за поддержку и ценные замечания.

Для цитирования: Пороховинова Е.А., Кутузова С.Н., Павлов А.В., Слободкина А.А., Якушева Т.В., Брач Н.Б. Коллекция генетических ресурсов льна Всероссийского института генетических ресурсов растений им. Н.И. Вавилова. Письма в Вавиловский журнал генетики и селекции. 2021;7(2):75-90. DOI 10.18699/LettersVJ2021-7-09

\section{Collection of flax genetic resources of the N.I. Vavilov All-Russian Institute of Plant Genetic Resources}

\author{
E.A. Porokhovinova (iD), S.N. Kutuzova (iD), A.V. Pavlov (iD, A.A. Slobodkina (iD), T.V. Yakusheva (iD), N.B. Brutch (iD)
}

Abstract: The conservation of crop genetic resources is mainly carried out ex situ. The highest numbers of flax accessions in the world (6243) are stored at the N.I. Vavilov All-Russian Institute of Plant Genetic Resources (VIR). The VIR flax collection was officially founded in 1922. It contains flax from all continents except Antarctica, from foreign Europe (1946 accessions) and Asia (1695), Russia (1696), North (301), South (248) Americas, Africa (220), Australia and Oceania (64). In total, the collection presents flax varieties from 83 countries. $10 \%$ of the collection are local forms, $40 \%$ are primitive selection samples, $24 \%$ are breeding material, $25 \%$ are developed varieties and 
lines, less than $1 \%$ is wild flaxes. The uniqueness of the VIR flax collection lies in the presence of more than 1900 accessions collected in 55 countries during more than 120 VIR expeditions. The replenishment of the collection can be divided into five stages related to historical events against which is took place. Before introduction the collection, all flax accessions undergo a comprehensive evaluation of the main morphological and economically valuable characters. Additional study of parts of the collection is aimed at determining the principles of creating and structuring the collection, assessing the influence of environmental conditions on the flax development, determining fiber quality by different methods, studying the seeds biochemical composition, genetic control of various flax traits. Conservation of genetic resources in a changing world is one of the primary tasks facing all states. VIR makes the greatest possible contribution to the solution to this task.

Key words: Linum usitatissimum; flax; linseed; plants genetic resources collection; gene bank; accessions; landraces; commercial variety; geographical origin.

For citation: Porokhovinova E.A., Kutuzova S.N., Pavlov A.V., Slobodkina A.A., Yakusheva T.V., Brutch N.B. Collection of flax genetic resources of the N.I. Vavilov All-Russian Institute of Plant Genetic Resources. Pisma v Vavilovskii Zhurnal Genetiki i Selektsii = Letters to Vavilov Journal of Genetics and Breeding. 2021;7(2):75-90. DOI 10.18699/LettersVJ2021-7-09 (in Russian)

\section{Введение}

Лен - одна из древнейших культур, возделываемых человеком. Самые ранние находки культурного льна датируются 8700-7000 гг. до н. э., а уже в эпоху бронзового и железного веков человек возделывал лен практически по всей Европе, Центральной и Южной Азии, Северной Африке, Закавказью (Зеленцов, 2017). Семена льна использовали в пищу и для получения масла. Из волокна изготавливали одежду, рыболовные снасти, веревки и т. д. В наши дни лен не утратил своего значения: все части растения (волокно, семена, полова, костра) находят применение во многих отраслях промышленности.

В зависимости от основного направления использования выделяют три типа льна: долгунец (на волокно), кудряш (на семена) и межеумок (на семена и волокно). Лен-кудряш в настоящее время практически нигде не возделывают, и под масличным подразумевают лен-межеумок.

По данным FAO', в 2019 г. лен-долгунец выращивали на площади почти 260 тыс. га и среди прядильных культур он занимал третье место после хлопчатника и джута. России принадлежит третье после Франции и Беларуси место в мире по площади возделывания прядильного льна. В 2020 г. в России высевали лен-долгунец на 52.6 тыс. га, в основном в Тверской, Смоленской, Нижегородской и Омской областях и Удмуртии. Урожай волокна в среднем составил 8 ц/га, достигая 11.5 ц/га в Алтайском крае (рис. 1, a, c; 2, a) 2, 3. Лен масличный в 2019 г. занимал 3.2 млн га в мире, т. е. примерно в 12 раз большую площадь, чем прядильный. Россия находится на втором месте после Казахстана по этому показателю (см. рис. 1, b, с) ${ }^{1}$. В 2020 г. в России высевали масличный лен на площади 1030 тыс. га, практически во всех регионах,

\footnotetext{
1 FAOSTAT domains: "crops processed", element: "Area harvested", crops: linseed, flax. Доступно: http://www.fao.org/faostat/ru/\#data/QC 2 Валовые сборы и урожайность сельскохозяйственных культур по Российской Федерации в 2020 г. Часть 2. Федеральная служба государственной статистики (Росстат). Главный межрегиональный центр. М., 2021. Доступно: https://rosstat.gov.ru/search?q=Вало вые+сборы++сельскохозяйственных+культур+в+2020\&date_ from $=\&$ content $=$ on \&date_to $=\&$ search_by=all\&sort=relevance

3 Посевные площади Российской Федерации в 2020 г. Федеральная служба государственной статистики (Росстат). Главный межрегиональный центр. М., 2021. Доступно: https://rosstat.gov.ru/ search?q=Посевные+площади+Российской+Федерации++в+2020 \&date_from $=\&$ content $=$ on\&date_to $=\&$ search_by=all\&sort=relevance
}

но больше всего в Омской и Челябинской областях и Алтайском крае. Урожай семян составил в среднем 8.1 ц/га, достигая 14.5 ц/га в Мордовии (см. рис. 2, b) 2,3.

Посевные площади льна в России можно значительно расширить, так как растение возможно использовать как резервную культуру для восполнения дефицита сырья в случае неурожая подсолнечника и сои (Лукомец и др., 2015). Эта работа должна основываться на создании новых сортов, приспособленных к разнообразным климатическим условиям нашей страны. Основой селекции любой культуры являются выявление и использование ее внутривидового разнообразия. На сегодняшний день наиболее эффективным и широко распространенным методом работы с генетическими ресурсами растений (ГРР) служит их сохранение и изучение ex situ. При этом основную часть сохраняемых образцов содержат в специализированных условиях - генных банках, которых во всем мире насчитывают более 1750. Они расположены на всех континентах и включают около 7.4 млн образцов, при этом 20-30\% являются оригинальными, а оставшаяся часть - дублеты других коллекций. В генбанках хранятся различные типы коллекций: национальные коллекции долгосрочного хранения, рабочие коллекции средне- и краткосрочного хранения и др. Около $45 \%$ всех образцов, представленных в генбанках мира, - зерновые культуры. Второе место занимают бобовые - $15 \%$ общего количества образцов. Овощные, плодовые и кормовые культуры составляют по 6-9\%. На долю масличных и прядильных культур приходится по 2-3\%. По состоянию на 2010 г., наибольшее количество образцов льна (5282) находится во Всероссийском институте генетических ресурсов растений им. Н.И. Вавилова (ВИР) ${ }^{4}$. В марте 2021 г. количество образцов льна в ВИРе достигло 6243.

\section{Внутривидовой состав коллекции}

Классификация культурного льна еще до конца не разработана. В коллекции ВИР использована упрощенная классификация Е.В. Эллади (1940) (табл. 1; см. рис. 3, а). Условно лен разделен на три типа: лен-долгунец - одностебельный, высотой 70-140 см, с компактным соцветием, прядильного направления использования; лен-кудряш - многосте-

\footnotetext{
4 ФАО 2010. Второй доклад о состоянии мировых генетических ресурсов растений для производства продовольствия и ведения
} с.-х. Рим, 2010. Доступно: http://www.fao.org/3/i1500r/i1500r00.htm 


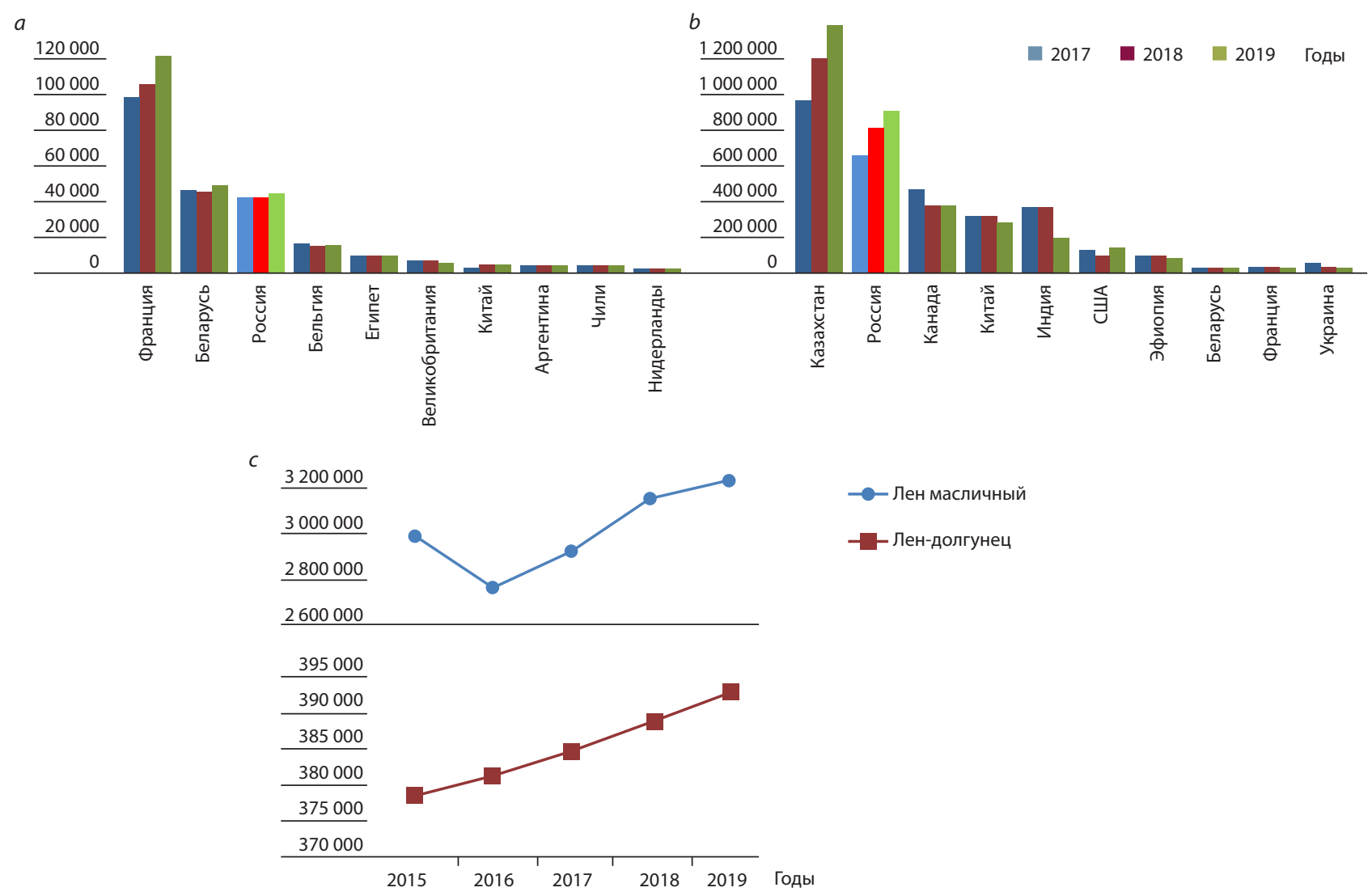

Рис. 1. Площади возделывания (га) льна-долгунца (a) и льна масличного $(b)$ в основных льносеющих странах; мировые площади возделывания (га) льна-долгунца и льна масличного (c), по данным FAO

Fig. 1. Cultivation areas (ha) of fiber flax (a) and linseed (b) in main flax growing countries; world cultivation areas (ha) of fiber flax and linseed (c) according to FAO data
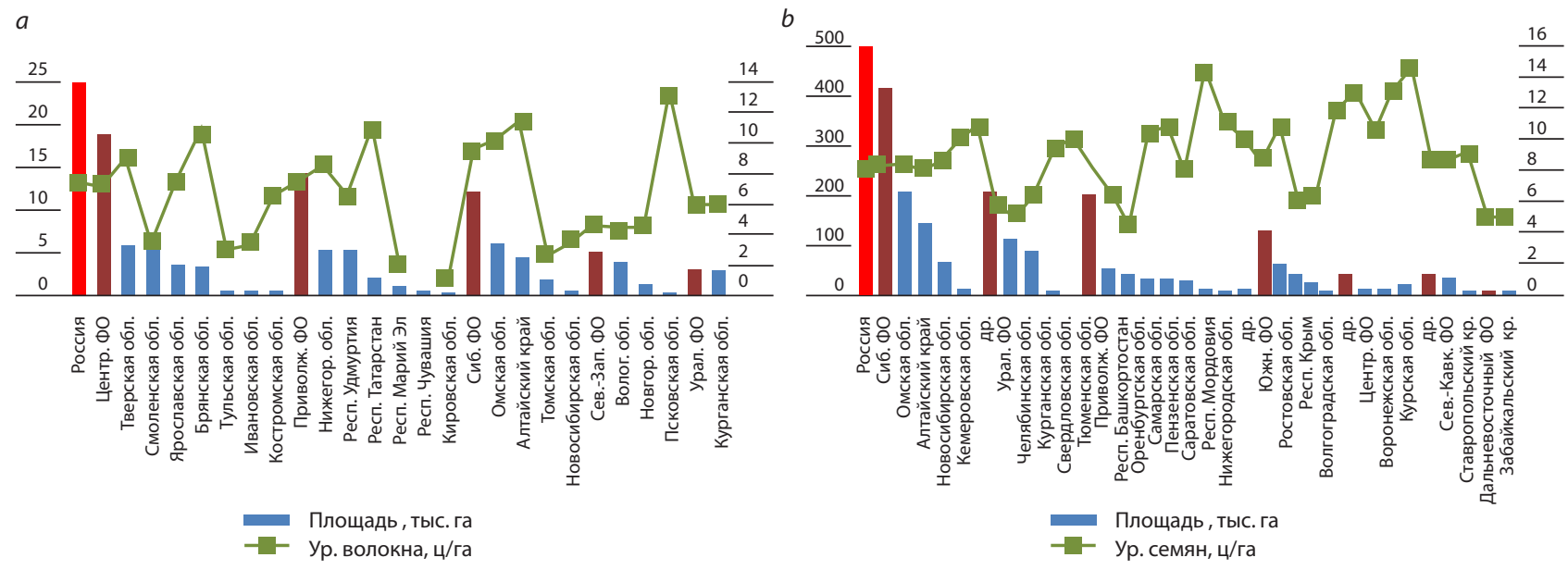

Рис. 2. Площади возделывания (га) и урожайность (ц/га) льна-долгунца (a) и льна масличного (b) в России, по данным Росстата Fig. 2. Cultivation area (ha) and yield (kg/ha) fiber flax (a) and linseed (b) in Russia according to Rosstat data

бельный, высотой 20-50 см, с большим числом коробочек, масличного направления использования; лен-межеумок одно- или двустебельный, высотой 50-80 см, с большим числом коробочек масличного направления использования, также рентабельный для производства волокна низкого качества.
Среди межеумков, реже кудряшей, встречаются крупносемянные формы, у большинства из которых объемные цветки и широколанцетные листья. Эти формы, как правило, имеют средиземноморское происхождение и по классификации еще К. Линнея относятся к крупносемянным льнам, которые в нашей коллекции приняты в ранге разновидностей. 

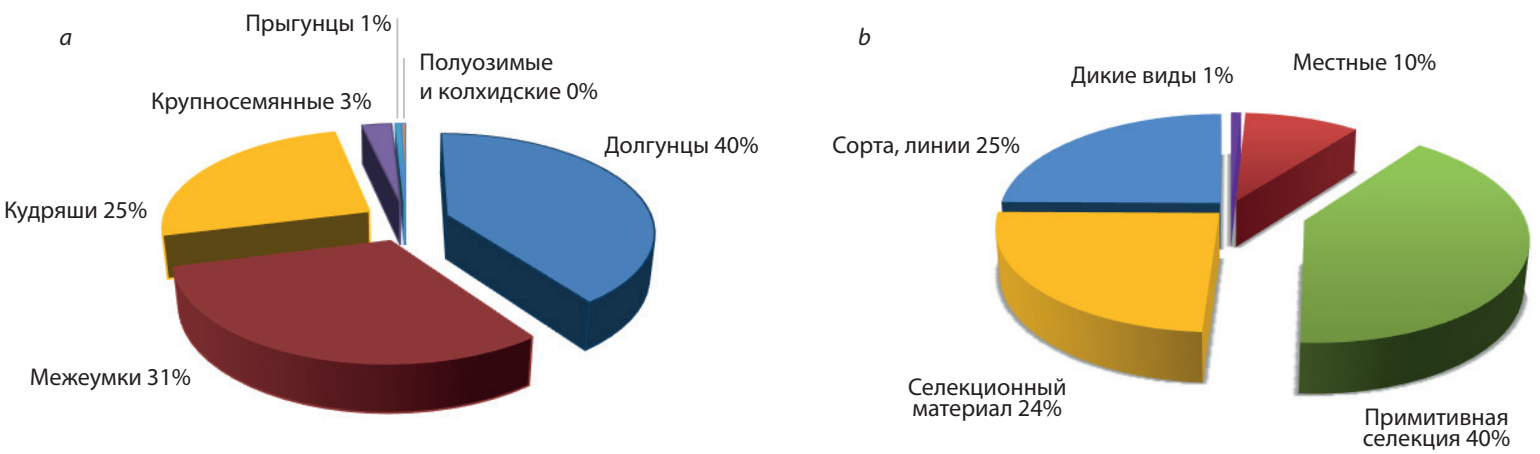

Рис. 3. Распределение образцов льна коллекции ВИР по типу (a) и статусу (b) образца

Fig. 3. Distribution of VIR flax accessions according to their type $(a)$ and status $(b)$

Таблица 1. Биологическая классификация, принятая при описании коллекции льна ВИР Table 1. Biological classification adopted for describing of the VIR flax collection

\begin{tabular}{|c|c|c|c|c|c|c|}
\hline \multirow[t]{2}{*}{ Тип льна } & \multicolumn{5}{|c|}{ Ботаническая классификация } & \multirow[t]{2}{*}{$\mathrm{N}$} \\
\hline & genus & species & variety & subvariety & forma & \\
\hline Долгунец & Linum L. & usitatissimum L. & elongatum Vav. et Ell. & elongatum & erecta & 2481 \\
\hline $\begin{array}{l}\text { Долгунец, } \\
\text { полуозимый }\end{array}$ & Linum L. & usitatissimum L. & elongatum Vav. et Ell. & elongatum & prostrata Vav. et Ell. & 1 \\
\hline Межеумок & Linum L. & usitatissimum L. & intermedium Vav. et Ell. & intermedium & erecta & 1917 \\
\hline $\begin{array}{l}\text { Межеумок, } \\
\text { крупносемянный }\end{array}$ & Linum L. & usitatissimum L. & intermedium Vav. et Ell. & latifolium L. & erecta & 167 \\
\hline $\begin{array}{l}\text { Межеумок, } \\
\text { полуозимый }\end{array}$ & Linum L. & usitatissimum L. & intermedium Vav. et Ell. & intermedium & prostrata Vav. et Ell. & 8 \\
\hline Кудряш & Linum L. & usitatissimum L. & humile Mill. & humile & erecta & 1572 \\
\hline $\begin{array}{l}\text { Кудряш, } \\
\text { крупносемянный }\end{array}$ & Linum L. & usitatissimum L. & humile Mill. & latifolium L. & erecta & 2 \\
\hline $\begin{array}{l}\text { Кудряш, } \\
\text { полуозимый }\end{array}$ & Linum L. & usitatissimum L. & humile Mill. & humile & prostrata Vav. et Ell. & 5 \\
\hline Прыгунец & Linum L. & usitatissimum L. & crepitans Dum. & & & 31 \\
\hline Колхидский & Linum L. & usitatissimum L. & colchicum & & & 7 \\
\hline
\end{tabular}

Еще более мелкая градация, подразновидность, существует для полуозимых форм, которые отличаются повышенной зимостойкостью в мягком климате Южной Европы и при подзимнем посеве осенью образуют стелющуюся розетку. Весной стебли принимают вертикальное положение и практически не отличаются от обычного межеумка. Чем-то похожи на полуозимые формы колхидские льны, считающиеся одним из возможных предков льна-долгунца: высокорослые ( 70 см), многостебельные - образуют розетку из нескольких стеблей в зависимости от густоты посева, облиственные, имеют мелкие семена и крайне позднеспелые. Все описанные выше формы хорошо скрещиваются между собой, чего нельзя сказать о последнем подвиде - льнепрыгунце (L. usitatissimum var. crepitans), особенностью кото- рого служат растрескивающиеся коробочки, что приводит к резкому выбрасыванию («выпрыгиванию») семян (Кутузова и др., 2015).

\section{Географическое разнообразие происхождения} образцов коллекции

Коллекция генетических ресурсов растений льна ВИР официально берет свое начало в 1922 г. с линий-отборов Л.Ф. Альтгаузена, ведущего селекционера льна России, и, по данным на март 2021 г., содержит 6243 образца. В ней присутствуют льны со всех континентов кроме Антарктиды: наибольшее число образцов из Европы (1946) и Азии (1695), России (1696); меньше - из Северной (301) и Южной (248) Америк, Африки (220), Австралии и Океании (64). Всего в 
Северная Америка

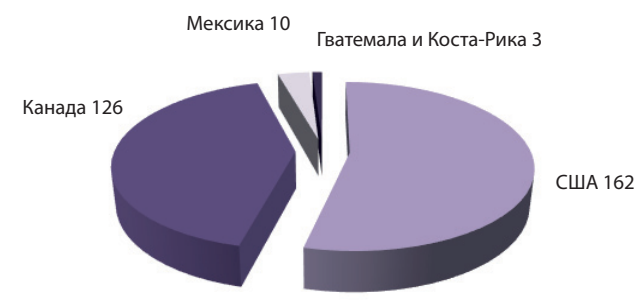

Азия
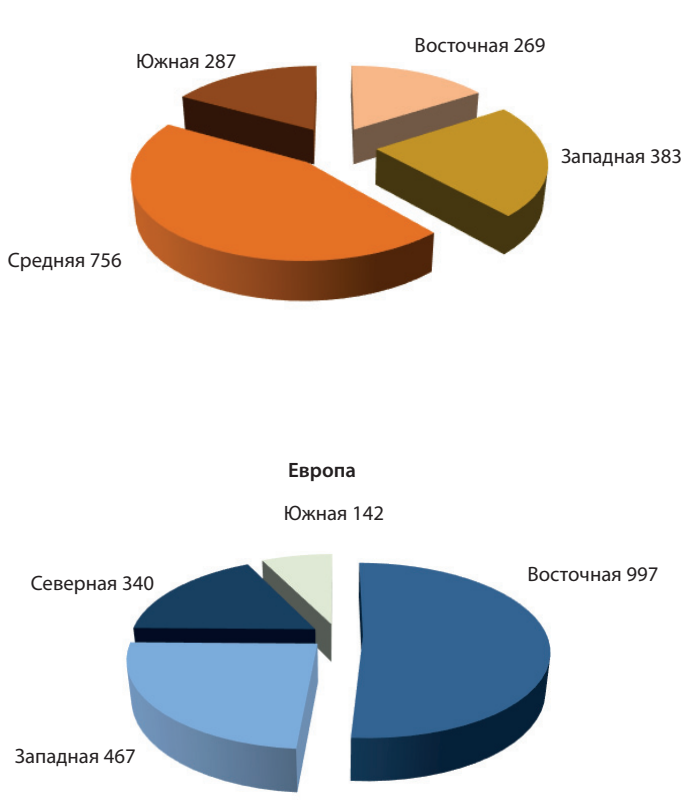

Россия

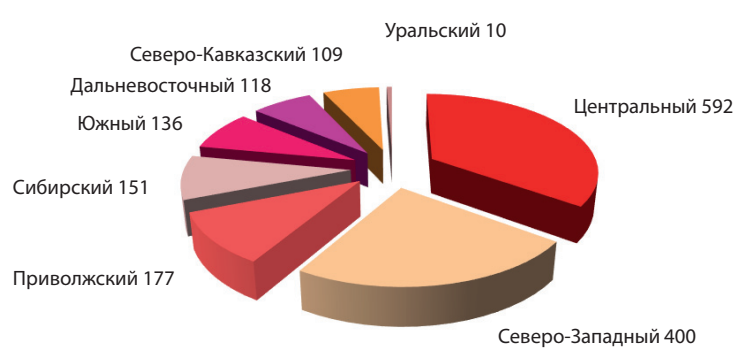

Южная Америка

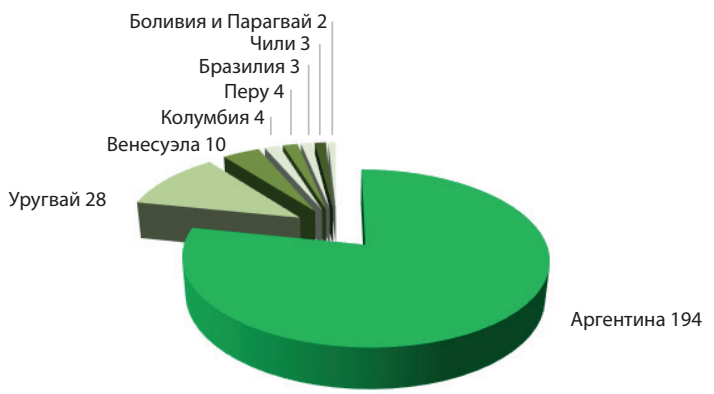

Африка
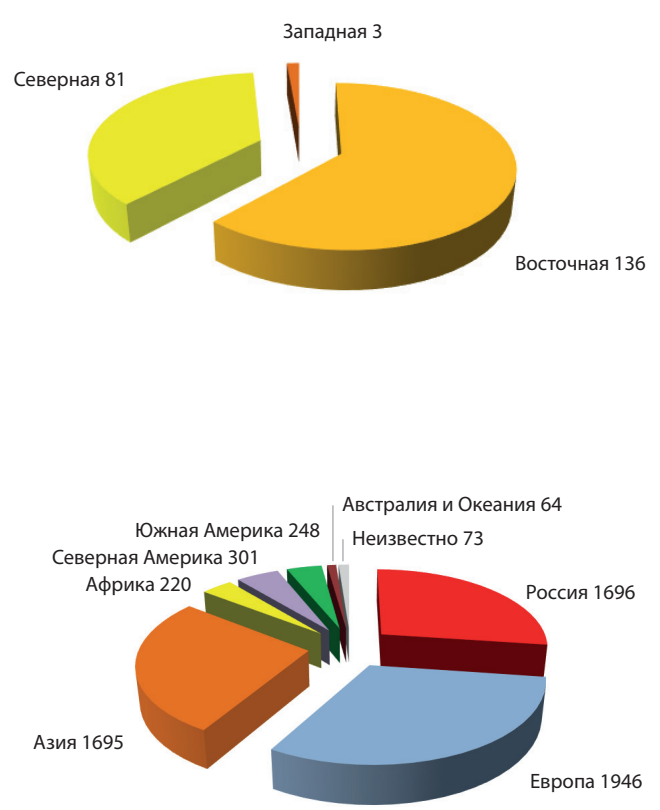

Рис. 4. Географическое происхождение образцов льна коллекции ГРР ВИР Fig. 4. Geographical origin of flax accessions from the VIR collection

коллекции представлено разнообразие льна 83 стран мира (см. рис. 4; табл. 1). Наибольшее число образцов получено из России (1696), стран бывшего СССР (Украины, Таджикистана, Узбекистана, Литвы, Казахстана, Беларуси и Армении), а также других регионов традиционного возделывания льна (Чехии, Венгрии, Германии, Нидерландов, Франции, Китая, Турции, Индии, Афганистана, США, Канады, Аргентины).
Русский лен в коллекции ВИР представлен образцами из всех федеральных округов (ФО). Наибольшее число образцов происходят из Центрального (592) и Северо-Западного (400), регионов традиционного возделывания прядильного льна. Кроме того, здесь же расположены три селекционных центра: ВНИИ льна, Смоленская опытная станция, Псковский НИИСХ (в настоящее время входящие в состав ФГБНУ 
Таблица 1. Распределение образцов коллекции ГРР льна ВИР по регионам происхождения

Table 1. Distribution of VIR flax accessions according to the regions of origin

\begin{tabular}{|c|c|c|c|c|c|}
\hline Регион & $\begin{array}{l}\text { Число } \\
\text { образцов }\end{array}$ & Регион & Число образцов & Регион & $\begin{array}{l}\text { Число } \\
\text { образцов }\end{array}$ \\
\hline Россия & 1696 & Азия & 1695 & Западная Африка & 3 \\
\hline Европа & 1946 & Восточная Азия & 269 & Нигерия & 3 \\
\hline Восточная Европа & 997 & Китай & 242 & Северная Африка & 81 \\
\hline Украина & 354 & Япония & 18 & Марокко & 40 \\
\hline Чехия & 244 & Корея & 6 & Египет & 20 \\
\hline Венгрия & 138 & Монголия & 3 & Тунис & 15 \\
\hline Беларусь & 136 & Западная Азия & 383 & Алжир & 4 \\
\hline Польша & 61 & Турция & 142 & Ливия & 2 \\
\hline Румыния & 42 & Армения & 111 & Северная Америка & 301 \\
\hline Болгария & 21 & Азербайджан & 47 & США & 162 \\
\hline Словакия & 1 & Грузия и Абхазия & 43 & Канада & 126 \\
\hline Западная Европа & 467 & Кипр & 13 & Мексика & 10 \\
\hline Германия & 144 & Израиль и Палестина & 9 & Гватемала & 2 \\
\hline Нидерланды & 138 & Ирак & 9 & Коста-Рика & 1 \\
\hline Франция & 97 & Иран & 5 & Южная Америка & 248 \\
\hline Великобритания & 54 & Сирия & 4 & Аргентина & 194 \\
\hline Бельгия & 20 & Средняя Азия & 756 & Уругвай & 28 \\
\hline Австрия & 6 & Таджикистан & 301 & Венесуэла & 10 \\
\hline Ирландия & 4 & Узбекистан & 266 & Колумбия & 4 \\
\hline Швейцария & 4 & Казахстан & 152 & Перу & 4 \\
\hline Северная Европа & 340 & Киргизия & 36 & Бразилия & 3 \\
\hline Литва & 203 & Туркмения & 1 & Чили & 3 \\
\hline Швеция & 55 & Южная Азия & 287 & Боливия & 1 \\
\hline Латвия & 44 & Индия & 166 & Парагвай & 1 \\
\hline Дания & 16 & Афганистан & 90 & Австралия и Океания & 64 \\
\hline Эстония & 13 & Пакистан & 28 & Австралия & 63 \\
\hline Финляндия & 8 & Бангладеш & 1 & Новая Зеландия & 1 \\
\hline Норвегия & 1 & Непал & 1 & Неизвестно & 73 \\
\hline Южная Европа & 142 & Шри-Ланка & 1 & Bcero & 6243 \\
\hline Португалия & 50 & Африка & 220 & & \\
\hline Хорватия & 32 & Восточная Африка & 136 & & \\
\hline Италия & 30 & Эфиопия & 123 & & \\
\hline Испания & 13 & Эритрея & 11 & & \\
\hline $\begin{array}{l}\text { бывш. } \\
\text { Югославия }\end{array}$ & 13 & Кения & 2 & & \\
\hline Греция & 2 & & & & \\
\hline Мальта & 1 & & & & \\
\hline Черногория & 1 & & & & \\
\hline
\end{tabular}


Таблица 2. Распределение образцов коллекции ГРР льна ВИР по регионам происхождения в России Table 2. Distribution of VIR flax accessions according to the regions of their origin in Russian Federation

\begin{tabular}{|c|c|c|c|}
\hline Регион & Число образцов & Регион & Число образцов \\
\hline Россия (всего) & 1696 & Приволжский ФО & 177 \\
\hline Центральный ФО & 592 & Кировская обл. & 47 \\
\hline Тверская обл. & 264 & Самарская обл. & 39 \\
\hline Московская обл. & 147 & Саратовская обл. & 29 \\
\hline Смоленская обл. & 71 & Удмуртская респ. & 25 \\
\hline Ярославская обл. & 58 & Пермский край & 14 \\
\hline Воронежская обл. & 15 & Волго-Вятский р-н & 7 \\
\hline Орловская обл. & 8 & Пензенская обл. & 7 \\
\hline Владимирская обл. & 6 & Ульяновская обл. & 3 \\
\hline Костромская обл. & 5 & Нижегородская обл. & 2 \\
\hline Курская обл. & 5 & Оренбургская обл. & 2 \\
\hline Брянская обл. & 4 & Чувашская Респ. & 2 \\
\hline Тамбовская обл. & 3 & Уральский ФО & 10 \\
\hline Тульская обл. & 3 & Тюменская обл. & 9 \\
\hline Ивановская обл. & 2 & Челябинская обл. & 1 \\
\hline Рязанская обл. & 1 & Сибирский ФО & 151 \\
\hline Северо-Западный ФО & 400 & Алтайский край & 66 \\
\hline Ленинградская обл. & 163 & Томская обл. & 29 \\
\hline Псковская обл. & 163 & Красноярский край & 13 \\
\hline Вологодская обл. & 38 & Респ. Тыва & 13 \\
\hline Архангельская обл. & 15 & Иркутская обл. & 11 \\
\hline Новгородская обл. & 8 & Омская обл. & 10 \\
\hline Респ. Карелия & 8 & Новосибирская обл. & 5 \\
\hline Респ. Коми & 5 & Западная Сибирь & 2 \\
\hline Южный ФО & 136 & Кемеровская обл. & 2 \\
\hline Краснодарский край & 87 & Дальневосточный ФО & 118 \\
\hline Ростовская обл. & 46 & Приморский край & 112 \\
\hline Волгоградская обл. & 3 & Забайкальский край & 2 \\
\hline Северо-Кавказский ФО & 109 & Респ. Саха (Якутия) & 2 \\
\hline Ставропольский край & 55 & Амурская обл. & 1 \\
\hline Респ. Дагестан & 46 & Хабаровский край & 1 \\
\hline Респ. Северная Осетия & 8 & Неизвестно & 3 \\
\hline
\end{tabular}


«Федеральный научный центр лубяных культур») и ВИР. Приволжский ФО, как пограничный регион возделывания прядильного и масличного льна (177), занимает третье место по количеству образцов, Сибирский (151) и Дальневосточный (118) округа представлены большей частью прядильным льном, Южный (136) и Северо-Кавказский (109) ФО масличным. Наименьшее число образцов (10) характерно для Уральского федерального округа (см. рис. 4; табл. 2).

\section{Мобилизация нового материала в коллекцию} В генбанках принято разделять образцы по статусу (Мамедова, Вишнякова, 2020). На данный момент примерно 10\% коллекции льна составляют местные формы, 40\% - образцы примитивной селекции, 24\% приходится на селекционный материал и 25\% - на более проработанные сорта и линии, менее $1 \%$ коллекции занимают дикие виды льна (см. рис. 3, b).

Коллекция ГРР ВИР охватывает практически все мировое разнообразие льна, что достигнуто в результате последовательной работы кураторов коллекции по привлечению материала.

В довоенные годы проводили тотальный сбор всего семенного материала, который был доступен как благодаря экспедициям, так и на выставках, по перепискам и обмену. В ВИР поступали все районированные сорта. Образцы высевали один-два года и принимали решение об их внесении в постоянный каталог. Однако часть образцов через несколько поколений репродукции начинала расщепляться, не вызревала или полностью погибала от болезней, поэтому были разработаны жесткие правила внесения образцов льна и многих других культур в постоянный каталог. Все поступившие в ВИР образцы получают интродукционные номера (временный каталог), уникальные и сквозные для всех культур, собранных в ВИРе. Под ними образцы льна изучают три года и только по результатам исследования и при достаточном количестве семян вносят в постоянный каталог, присваивая новый номер.

Все однородные образцы добавляют в коллекцию, даже если на первый взгляд они не несут каких-либо ценных признаков, так как невозможно предсказать, какие их характеристики окажутся важными в будущем. Если поступивший материал неоднороден, то в зависимости от наличия ценных признаков куратор принимает решение списать образец или отобрать из него ценные и необычные формы с последующим присвоением им новых номеров интродукции. Во временном интродукционном каталоге сейчас находятся около 500 единиц хранения льна, из которых около 100 образцы диких видов, характеризующиеся гетеростилией и самонесовместимостью, а значит, сложностью поддержания; около 300 линий генколлекции и примерно 100 сортов селекционного материала - в первичном изучении.

Уникальность коллекции льна ВИР заключается в наличии более 1900 образцов, собранных в 55 странах мира в результате более чем 120 экспедиций. На данный момент в коллекции находятся 1448 образцов из довоенных сборов И.А. Минкевича (652), Н.И. Вавилова (344), П.М. Жуковского (126), Е.А. Столетова (65) и др.; образцы ранних послевоенных лет (162), сборов Д.В. Тер-Аванесяна (46), Т.Н. Шевчука (30) и др., а также экспедиций с конца 1960-х гг. по настоя- щее время (319). Это золотой фонд нашей планеты, который в большей степени включает образцы Таджикистана (249), Узбекистана (221), России (199), Украины (147), Турции (127), Армении (104), Индии и Пакистана (115), Эфиопии и Эритреи (94), Китая (75) и Казахстана (72).

В ВИРе до недавнего времени интенсивно проводили обмен и выписку современного селекционного материала как из ведущих научных учреждений мира, так и небольших селекционных станций, поэтому в коллекции репрезентативно представлен проработанный материал (1510 образцов), сорта и линии (1551) разных направлений селекции, актуальных для почти каждого региона мира. В коллекции ВИР хранится большинство районированных в разные периоды на территории бывшего СССР сортов льна - как масличного, так и прядильного использования (Кутузова и др., 2005). Из 66 современных районированных сортов прядильного льна в коллекции представлены 55, а из 44 масличного - 25 образцов 5 . Часть из отсутствующих в каталоге сортов уже изучают в ВИРе и в ближайшее время внесут в постоянный каталог.

Пополнение коллекции ГРР льна ВИР можно разделить на пять этапов (см. рис. 5). Первый этап - довоенный, 19221940 гг. Характеризуется массовостью поступления: за год в каталог вносили более 300 образцов местных сортов и кряжей - наиболее оригинального материала, созданного народной селекцией до начала эры современной селекции и представляющего золотой фонд важнейших селекционных признаков. Также период включает централизованные поступления с выставок, сортоучастков, обмен образцами с зарубежными исследователями; поступление первых селекционных сортов. На момент начала Великой Отечественной войны коллекция составляла 5522 образца, за годы блокады из них погибли 2606.

Второй этап - 1948-1967 гг. Охватывает послевоенные годы до окончания Зеленой революции в сельском хозяйстве, с одной стороны, и гонений на генетиков в СССР, с другой. Закончился поступлением более 1100 образцов, в основном зарубежных сортов и проработанного селекционного материала. Интересно, что с 1960 г. начинают поступать сорта/линии из генколлекций других стран (США, Великобритания, Нидерланды, Индия), однако генотип прописан в названии сорта. Многие из этих линий были довоенного происхождения, то есть как кураторы, так и мировое сообщество целенаправленно восстанавливали утраченную коллекцию (Сизов и др., 1968).

Третий этап - 1968-1990 гг., 1048 образцов. Ознаменован расцветом взаимодействия ВИРа с генбанками других стран и ведущими генетиками как СССР, так и зарубежья. В коллекцию по обмену от генбанков поступили линии из Франции (INRA), США, образцы из Германии (IPK), Пакистана. Возобновлены генетические исследования в самом ВИРе: коллекцию пополнили как исходные линии по устойчивости к ржавчине (Melampsora lini (Pers.) Lev.), так и первые доноры, созданные с помощью насыщающих скрещиваний этих линий и сорта-эталона качества волокна -

\footnotetext{
5 Государственная комиссия по испытанию и охране селекционных достижений (ФГБУ «Госсорткомиссия»). Доступно: https://gossortrf. ru/wp-content/uploads/2020/03/FIN_reestr_dop_12_03_2020.pdf
} 


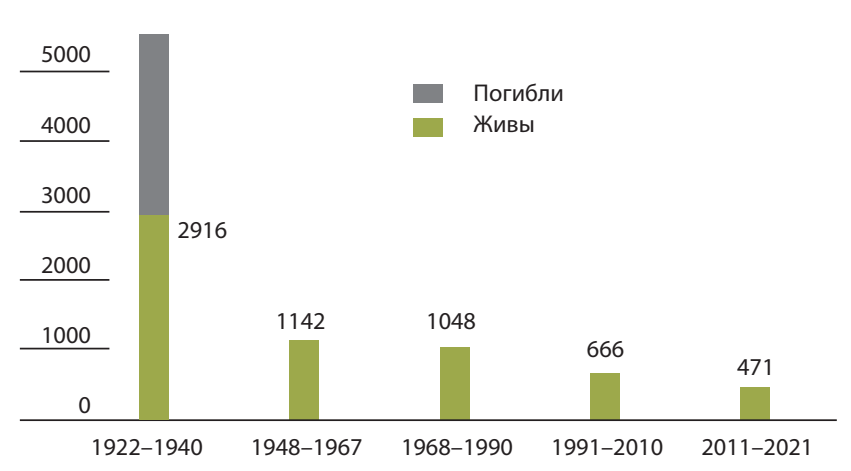

Рис. 5. Поступление образцов льна в коллекцию ВИР с 1922 по 2021 г.

Fig. 5. Receipt of flax accessions in VIR collection from 1922 to 2021

Оршанский 2. В этот период в СССР интенсивно ведут работы по искусственному мутагенезу льна и в коллекцию поступают стабильные линии, полученные с его использованием как селекционерами Литвы (К.П. Бачялис, ЛитНИИЗ, Упите), так и России (И.Я. Шаров, МоВИР, Истра, Московская обл.). В это же время интенсивно создают сорта как прядильного, так и масличного направлений использования, что также отражается в коллекции (Кутузова и др., 19916; Питько и др., 1994).

Четвертый этап - 1991-2010 гг. Наименее продуктивный (666 образцов), но интересный для коллекции. Последствия развала СССР сказались не сразу: первые годы охарактеризованы значительными поступлениями доноров различных хозяйственно ценных признаков (качества волокна, скороспелости, устойчивости к ржавчине, фузариозу) от селекционеров России, в том числе ВИРа и Украины (Кутузова и др., 2000), а также линий, полученных с помощью мутагенеза в Литве и России. Значительное количество образцов масличного льна поступило из Узбекистана (Бахмальского участка Узбекского НИИ земледелия). Возможно, это связано с тем, что селекционеры пытались спасти свой материал от гибели, передав его в ВИР. В коллекции, наконец, появляются последние линии из генколлекции по устойчивости к ржавчине Г. Флора, однако не из США, а Австралии. Крайне интересный материал получен из канадского генбанка и Индии; начались первые поступления из Китая.

Последний, пятый, этап - 2011-2021 гг. Ознаменован интенсивным обменом образцами с институтами из различных провинций Китая, чешской компанией AGRITEC и французской Terre de Lin - лидерами по селекции и возделыванию льна в своих странах, которые предоставили не только свой селекционный материал, но и образцы другого происхождения. Поступили интересные образцы льна из Канады, в том числе сорт Bethune, геном которого секвенирован (Wang et al., 2012). В коллекцию также внесены последние линии, полученные с помощью мутагенеза в Литве и России. Важно отметить, что химический мутагенез у льна не теряет свои позиции и с его помощью продолжают получать востребованный в селекции материал, но только уже селекционеры Чехии и на масличном льне. В основную коллекцию включен значительный блок линий из генколлекции ВИР с идентифицированными генами окрасок, а также устойчивости к ржавчине. В очереди на внесение в коллекцию стоят следующие образцы из Чехии и Франции, а также селекционные формы из Китая и Канады; в планах и дальше регистрировать генколлекцию ВИР.

Паспортная часть коллекции доступна на сайте ВИР (http://db.vir.nw.ru/virdb/maindb). Для англоязычных пользователей паспортная база данных представлена на сайте European Search Catalogue for Plant Genetic Resources (EURISCO) (https://eurisco.ipk-gatersleben.de/apex/ $f ? p=103: 11: .: .:$ P11_AEGIS,P11_MLS:999,999).

\section{Базовое изучение образцов коллекции ГРР льна ВИР}

Все образцы коллекции льна проходят трехлетнее изучение на делянках площадью 1 м² (Кутузова, Питько, 1988). Оценивают их единообразие по морфологическим признакам (см. рис. 6, 7) - окраске гипокотиля, окраске, размеру и форме цветка, семян, растрескиваемости коробочек, времени начала и полного цветения и созревания растений (5 и 75\%). Рассчитывают периоды всхода - цветения, цветения - созревания и всхода - созревания. Измеряют общую и техническую длину растения, кустистость; определяют продуктивность по семенам и массу 1000 зерен (см. рис. 8), устойчивость к полеганию. До 1990 г. проводили сквозное исследование коллекции на содержание масла и его йодное число (показатель ненасыщенности жирных кислот масла). Большая часть коллекции льна-долгунца изучена по продуктивности по соломе и волокну, а также качеству длинного волокна (разрывной нагрузке, гибкости, тонине, номеру волокна, относительной разрывной нагрузке) (см. рис. 9). Около 500 образцов коллекции изучено по жирнокислотному составу масла. Все новые образцы льна-долгунца и часть масличного исследуют на искусственном инфекционном фоне по ржавчине (M. lini) (Кутузова и др., 2020). До 1980-х гг. изучение коллекции льна проводили на искусственном инфекционном фоне по фузариозу (Fusarium oxysporum Schl. f. lini (Boll.)).

Практически по всем исследованным признакам размах изменчивости между образцами в коллекции превышает среднее значение сорта-стандарта в 1.5-2 раза (см. рис. 9), что указывает на широкий охват представленного в ней внутривидового разнообразия.

\section{Компетенции (продвинутое изучение образцов) коллекции ГРР льна ВИР}

Коллекцию льна активно изучают в ВИРе и других научных учреждениях. Наиболее исследованы следующие направления (представлены ссылки на первоначальные работы сотрудников ВИРа и современные публикации).

- Создание и структурирование коллекции:

- экспедиционный сбор и анализ связи географического происхождения с фено- и генотипом льна (Вавилов, 1926; Эллади, 1940);

- разработка принципов работы с коллекцией генетических ресурсов льна (Кутузова, Питько, 1988; Брач, Пороховинова, 2011a; Nozkova et al., 2016); 


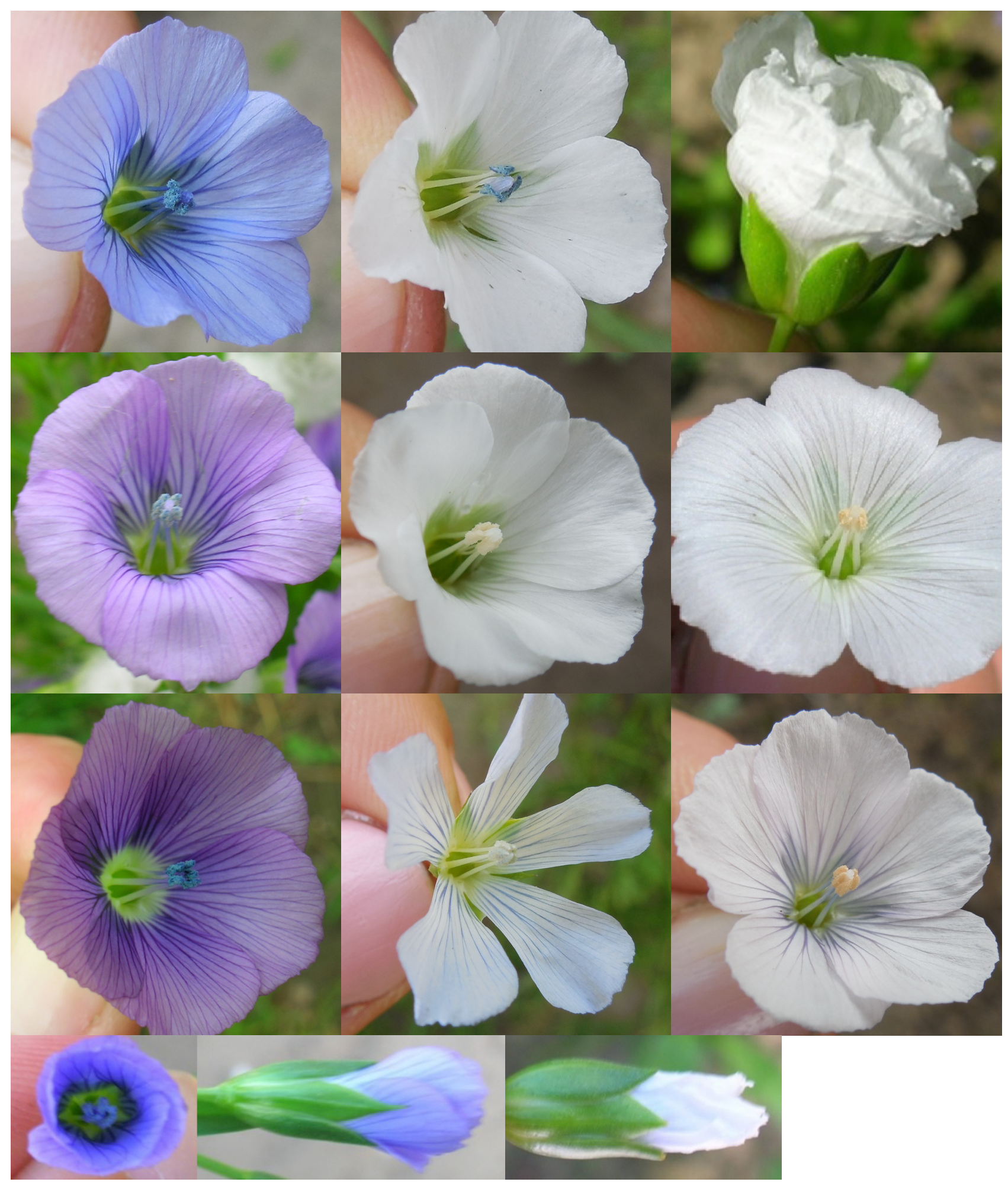

Рис. 6. Разнообразие образцов ГРР льна ВИР по окраске и форме цветка

Fig. 6. Variety of VIR flax accessions by color and flower shape 

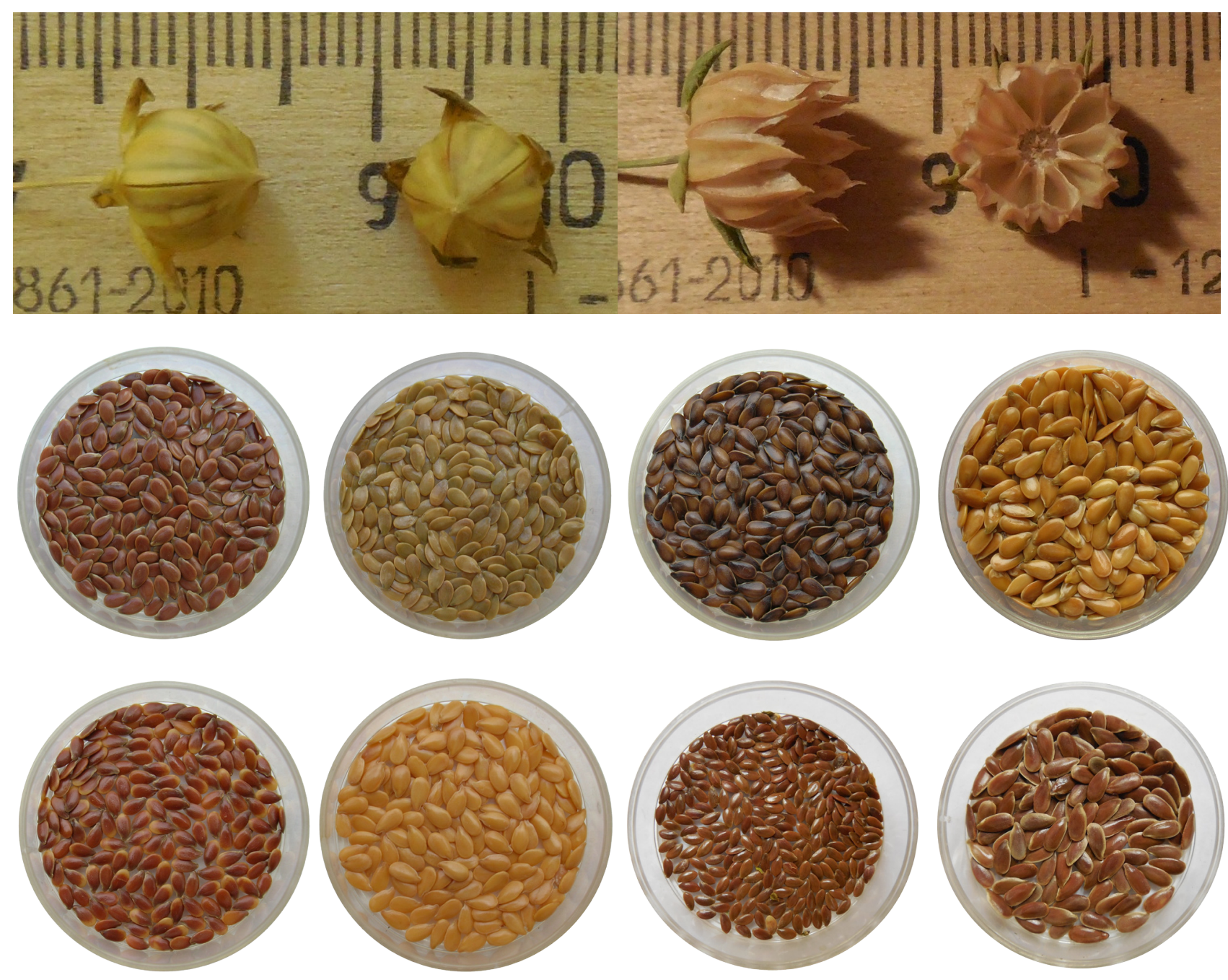

Рис. 7. Разнообразие образцов ГРР льна ВИР по растрескиваемости коробочек, размеру и цвету семян

Fig. 7. Variety of VIR flax accessions according to dehiscence of bolls, size and color of seeds

- внутривидовая классификация льна (Эллади, 1940; Синская, 1954; Кутузова и др., 2015);

- анализ доместикации льна (Вавилов, 1926; Эллади, 1940) и возможность стабилизации его фенотипов в генколлекции (Пороховинова и др., 2018).

- Влияние условий среды на развитие льна:

- эколого-географическое изучение льна (Иванов, 1926; Лебедев, Эверт, 1928; Кутузова и др., 1991а; Гаврилова и др., 2007; Брач и др., 20156; Пороховинова и др., 2016);

- изучение фотопериодической чувствительности льна (Сизов, 1955; Синская, 1954; Домантович и др., 2010; Брач и др., 2015a, 6; Pavlov et al., 2018; Brach et al., 2020);

- влияние изменения климатических условий на проявление признаков льна (Новикова и др., 2013);

- устойчивость льна к засухе (Кутузова и др., 2009);

- устойчивость льна к кадмию (Брач и др., 2018);

- влияние биологических препаратов на урожайность и качество волокна льна (Павлов и др., 2019).
- Качество волокна льна:

- комплексная оценка качества волокна льна (Лебедев, Эверт, 1928; Брач и др., 2010, 2011а, б);

- биохимический состав волокна льна и его качество (Brutch et al., 2008; Забивалова и др., 2009);

- анатомическое строение стебля льна и его связь с хозяйственно ценными признаками (Сизова, 1952; Домантович и др., 2010; Pavlov et al., 2018);

- подбор исходного материала для селекции льна (Кутузова и др., 19916, 2010, 2018; Брач и др., 20156; Попова и др., 2015).

- Биохимический состав семян льна:

- биологическое разнообразие льна по биохимическому составу масла семян (Иванов, 1926; Брач и др., 2016) и молекулярно-генетическое исследование низкой линоленовости масла семян льна (Пороховинова и др., 20196);

- биохимический состав и физические свойства слизи семян льна (Pavlov et al., 2014; Пороховинова и др., 2017); 

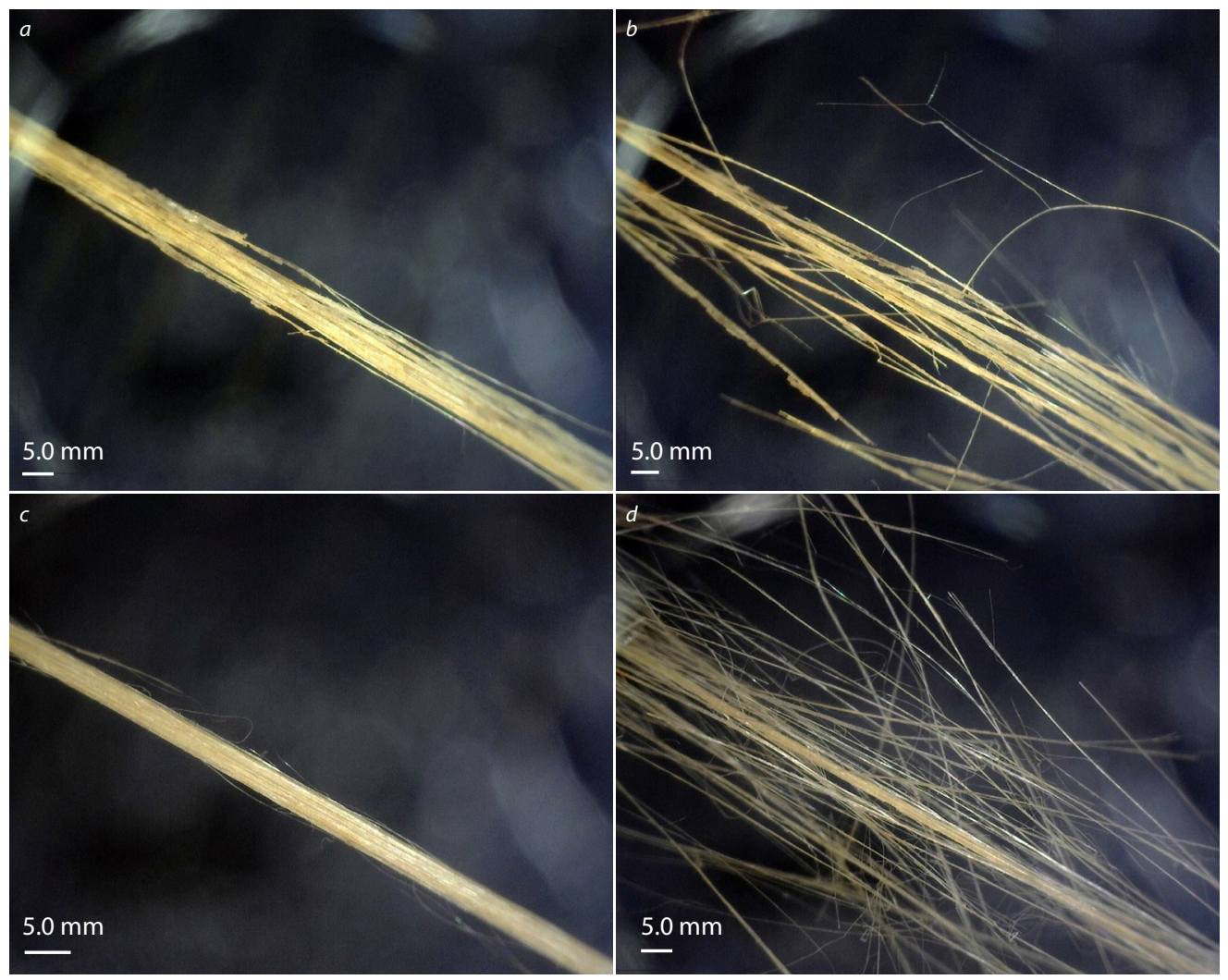

Рис. 8. Волокно льна, контрастное по качеству

$a$ - волокно плохого качества до испытания на разрыв; $b$ - волокно плохого качества после испытания на разрыв; $c$ - волокно хорошего качества до испытания на разрыв; $d$-волокно хорошего качества после испытания на разрыв

Fig. 8. Flax fiber of contrasting quality

$a$ - poor quality fiber before tensile test; $b$ - poor quality fiber after tensile test; $c$ - fiber of good quality before breaking test; $d$ - good quality fiber after tensile test

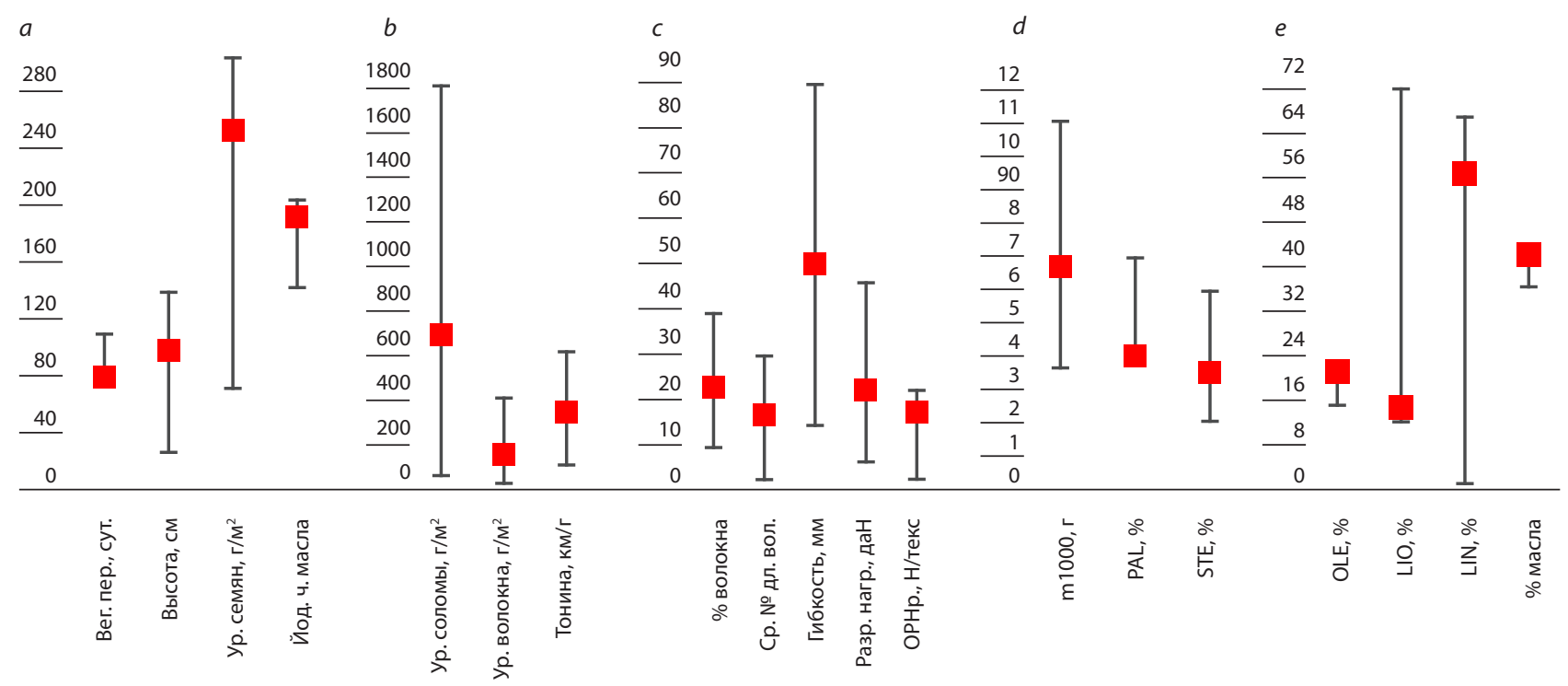

Рис. 9. Разнообразие образцов ГРР льна по хозяйственно ценным признакам

Ср. № дл. вол. - средний номер длинного волокна; OPHр - расчетная относительная разрывная нагрузка; $\mathrm{m} 1000$ - масса 1000 семян; PAL, STE - пальмитиновая и стеариновая кислоты в масле; OLE, LIO, LIN - олеиновая, линолевая и линоленовая кислоты в масле; \% масла в семенах льна (Кутузова и др., 19916, 2000, 2018; Низова и др., 2006; Питько и др., 1994; Брач и др., 2011а; Пороховинова и др., 20196)

Fig. 9. Variety of VIR flax accessions according to economically valuable traits

$a$ - growing season, days; total height, $\mathrm{cm}$; seed yield, $\mathrm{g} / \mathrm{m}^{2}$; iodine number of oil; $b$ - straw and fiber yield, $\mathrm{g} / \mathrm{m}^{2}$; long fiber fineness, $\mathrm{km} / \mathrm{g} ; \mathrm{c}$ - total fiber yield, $\%$; breaking load, daN; flexibility, mm; average number of long fibers; relative breaking load, calculated, N/tex; $d$-the mass of 1000 seeds, g; \% palmitic and stearic acids in oil; $e$ - the percentage of oleic, linoleic, linolenic acids in the oil; \% oil in flax seeds (Kutuzova et al., 1991 b, 2000, 2018; Pit'ko et al., 1994; Nizova et al., 2006; Brutch et al., 2011a; Porokhovinova et al., 2019b) 
Collection of flax genetic resources of the N.I. Vavilov

All-Russian Institute of Plant Genetic Resources
- изучение метаболома семян льна (Пороховинова и др., не опубл.).

- Генетический контроль признаков льна:

- создание на основе коллекции ГРР льна ВИР генетической коллекции по различным признакам (Кутузова, 1978; Пороховинова и др., 2013, 2018);

- изучение и генетический контроль устойчивости льна к ржавчине, создание доноров устойчивости к ржавчине (Кутузова, 1978; Kutuzova et al., 2019);

- изучение высоты растения и продолжительности фаз вегетационного периода и их генетический контроль; создание доноров скороспелости (Брач, 2005);

- генетический контроль морфологических признаков льна (Пороховинова и др., 2019а);

- ЦЦМС и восстановление фертильности у льна (Рыкова, 1979; Пороховинова, 2015);

- изучение связи морфологических и хозяйственно ценных признаков льна (Брач, Пороховинова, 20116; Пороховинова и др., 2017; Pavlov et al., 2018).

\section{Заключение}

Коллекция ГРР льна ВИР - динамически развивающаяся структура, в которой неразделимо связаны интродукция, сохранение и изучение образцов, включая всестороннее фено- и генотипирование, анализ происхождения и родословных, а также сведений, полученных из литературных источников. Только хорошо проработанная коллекция может служить для целей как фундаментальной науки, так и селекции. К сожалению, в наших знаниях еще остаются белые пятна, связанные с изучением льна и большим объемом работ в довоенные годы, репрессиями против Н.И. Вавилова и его соратников. В ВИРе создают базы данных по изучению коллекции ГРР льна, но они достаточно фрагментарны и из-за правового вакуума по их представлению и визуализации практически не доступны широкой общественности. Сохранение генетических ресурсов в изменяющемся мире - одна из первостепенных задач, стоящих перед всеми государствами. Специалисты Всероссийского института генетических ресурсов растений им. Н.И. Вавилова вносят неоценимый вклад в решение этого вопроса.

\section{Список литературы / References}

Брач Н.Б., Брач Е.А., Забегаева О.Н. Вариабельность устойчивости сортов льна к различным концентрациям кадмия в фазе проростков. В: Генофонд и селекция растений. Материалы IV Международной научно-практической конференции. 2018;54-58.

[Brutch N.B., Brutch E.A., Zabegaeva O.N. Variability of flax varieties resistance to different cadmium concentrations in seedlings stage. In: Gene pool and plant breeding. Materials of the IV International Scientific and Practical Conference. 2018;54-58. (in Russian)]

Брач Н.Б. Создание доноров скороспелости льна-долгунца. В: Генетические ресурсы культурных растений. Проблемы мобилизации, инвентаризации, сохранения и изучения генофонда важнейших сельскохозяйственных культур для решения приоритетных задач селекции. Тезисы докладов Международной научно-практической конференции. Всероссийский научно-исследовательский институт растениеводства им. Н.И. Вавилова. 2001;218-220.

[Brutch N.B. Creation of fiber flax donors of earliness. In: Genetic resources of cultivated plants. Problems of mobilization, inventory, conservation and evaluation of the gene pool of the most important agricultural crops for solving priority problems of breeding.
Abstracts of the International Scientific and Practical Conference. N.I. Vavilov All-Russian Research Institute of Plant Industry. 2001;218220. (in Russian)].

Брач Н.Б. Влияние условий выращивания на проявление и наследование признаков льна-долгунца. Труды по прикладной ботанике, генетике и селекции. 1999;156:40-45.

[Brutch N.B. Influence of the conditions of growth on manifestation and inheritance of fibre-flax characters. Proceedings on Applied Botany, Genetics and Breeding. 1999;156:40-45. (in Russian)]

Брач Н.Б. Изучение динамики цветения льна в условиях юга Португалии. Масличные культуры. Научно-технический бюллетень Всероссийского научно-исследовательского института масличных культур. 2005;2(133):69-75

[Brutch N.B. Evaluation of flax flowering dynamics in conditions of southern Portugal. Oil crops. Scientific and Technical Bulletin of VNIIMK. 2005;2(133):69-75. (in Russian)]

Брач Н.Б, Домантович А.В., Кошкин В.А., Павлов А.В., Матвиенко И.И. Каталог мировой коллекции ВИР. Выпуск 822. Линии генетической коллекции льна в условиях длинного и короткого дня. СПб: Изд-во ВИР, 2015а.

[Brutch N.B., Domantovich A.V., Koshkin V.A., Pavlov A.V., Matvienko l.I. Catalog of VIR world collection. Issue 822. Lines of flax genetic collection in conditions of long and short day. St. Petersburg: VIR, 2015a. (in Russian)]

Брач Н.Б., Домантович А.В., Кошкин В.А., Санин А.А., Косых Л.А. Интенсивность роста и развития линий льна с различной фотопериодической чувствительностью на широтах, традиционных для выращивания льна-долгунца и межеумка. Труды по прикладной ботанике, генетике и селекции. 20156;176(2): 210-224. DOI 10.30901/2227-8834-2015-2-210-224.

[Brach N.B., Domantovich A.V., Koshkin V.A., Sanin A.A., Kosykh L.A. Intensity of growth and development of flax lines with different photosensitivity in the latitudes traditional for flax and linseed. Proceedings on Applied Botany, Genetics and Breeding. 20156;176(2):210-224. DOI 10.30901/2227-8834-2015-2-210-224. (in Russian)]

Брач Н.Б., Павлов А.В., Кутузова С.Н., Пороховинова Е.А. Перспективы селекционного улучшения качества льноволокна. Труды по прикладной ботанике, генетике и селекции. 2011;167:58-77. [Brutch N.B., Pavlov A.V., Kutuzova S.N., Porokhovinova E.A. Prospects of flax fibre quality improvement by breeding. Proceedings on $A p$ plied Botany, Genetics and Breeding. 2011;167:58-77. (in Russian)]

Брач Н.Б., Пороховинова Е.А. Метод сравнительного анализа результатов изучения количественных признаков образцов растений, выращенных в различные годы (метод приведенных средних). Труды по прикладной ботанике, генетике и селекции. 2011a;167:36-40.

[Brutch N.B., Porokhovinova E.A. Method of comparative analysis used to assess the results of evaluating quantitative characters of plant accessions grown in different years (method of reduced average values). Proceedings on Applied Botany, Genetics and Breeding. 2011a;167:36-40. (in Russian)]

Брач Н.Б., Пороховинова Е.А. Связи морфологических и хозяйственно ценных признаков у гибридов между линиями льна, контрастными по этим характеристикам. Труды по прикладной ботанике, генетике и селекции. 20116;167:78-89.

[Brutch N.B., Porokhovinova E.A. Links between the morphological and agronomic characters in hybrids of lines with different manifestation of these traits. Proceedings on Applied Botany, Genetics and Breeding. 2011b;167:78-89. (in Russian)]

Брач Н.Б., Пороховинова Е.А., Шеленга Т.В. Инновационные возможности селекции масличного льна, ориентированной на различный состав масла. Достижения науки и техники АПК. 2016;30(6):5-8.

[Brutch N.B., Porokhoviniva E.A., Shelenga T.V. Innovative possibilities of oil flax breeding orientated at the different oil composition. Dostizheniya nauki i tekhniki APK. 2016;30(6):5-8. (in Russian)]

Брач Н.Б., Шаров И.Я., Павлов А.В., Пороховинова Е.А. Разнообразие признаков льна, связанных с формированием волокна, и влияние условий выращивания на их проявление. Экологическая генетика. 2010;8(1):25-35.

[Brutch N.B., Sharov I.Y., Pavlov A.V., Porokhovinova E.A. Diversity of flax characters associated with fibre formation and environmental 
influence on their formation. Russian Journal of Genetics: Applied Re search. 2011;1(5):361-370. DOI 10.1134/S2079059711050042]

Вавилов Н.И. Центры происхождения культурных растений. Труды по прикладной ботанике, генетике и селекции. 1926;16(2):5-138. [Vavilov N.I. Centers of cultivated plants origin. Proceedings on Ap plied Botany, Genetics and Breeding. 1926;16(2):5-138. (in Russian)]

Гаврилова В.А., Дубовская А.Г., Конькова Н.Г., Подольная Л.П., Григорьев С.В., Брач Н.Б., Селиванов Д.Г., Рубина Т.В., Низова Г.К., Пороховинова Е.А. Изменчивость хозяйственно ценных признаков масличных культур при эколого-географических испытаниях Сельскохозяйственная биология. 2007;42(5):26-40.

[Gavrilova V.A., Dubovskaya A.G., Kon'kova N.G., Podol'naya L.P., Grigor'ev S.V., Brach N.B., Selivanov D.G., Rubina T.V., Nizova G.K., Porokhovinova E.A. Variability of economic determinants in oil-bearing crops during ecologo-geographic tests. Sel'skokhozyaistvennaya Bi ologiya = Agricultural Biology. 2007;42(5):26-40. (in Russian)]

Домантович А.В., Брач Н.Б., Кошкин В.А. Влияние короткого дня на признаки, связанные с формированием волокна, у линий льна генетической коллекции ВИР. В: Генетические ресурсы растений и селекция. Материалы конференции молодых ученых и аспи рантов. ВИР, 2010;95-104

[Domantovich A.V., Brutch N.B., Koshkin V.A. Short day influence on the characters connected with fiber formation in lines of VIR flax genetic collection. In book: Plants genetic resources and breeding Abstracts of the young scientists and PhD students Conference. VIR, 2010;95-104. (in Russian)]

Забивалова Н.М., Бочек А.М., Кутузова С.Н., Лаврентьев В.К. Влияние химического состава и структурной организации волокон льна разных сортов на их деформационно-прочностные и физикохимические свойства. Вестник Санкт-Петербургского государ ственного университета технологии и дизайна. 2009;2(17):44-49. [Zabivalova N.M., Bochek A.M., Kutuzova S.N., Lavrentiev V.K. Influence of chemical composition and structural organization in flax fibers of different sorts on their deformation-strength and physicochemical properties. Vestnik of St. Petersburg State University of Technology and Design. 2009;2(17):44-49. (in Russian)]

Зеленцов С.В. История культуры льна в мире и России. Масличные культуры. Научно-технический бюллетень Всероссийского научно-исследовательского института масличных культур. 2017;1(169):93-103.

[Zelentsov S.V. History of flax crop in the world and Russia. Oil crops. Scientific and Technical Bulletin of VNIIMK. 2017;1(169):93-103. (in Russian)]

Иванов Н.Н. Изменчивость в химическом составе семян масличных растений в зависимости от географических факторов. Труды по прикладной ботанике, генетике и селекции. 1926;16:3-59.

[Ivanov N.N. Variability of oil plants seeds chemical composition depending on geographical factors. Proceedings on Applied Botany, Genetics and Breeding. 1926;16:3-59. (in Russian)]

Кутузова С.Н. Генетический анализ устойчивости льна-долгунца к ржавчине Melampsora lini (Pers.) Lev. Генетика. 1978;14(9):1620 1624.

[Kutuzova S.N. Genetic-analysis of fiber flax resistance to rust (Melampsora lini (Pers.) Lev. Russian Journal of Genetics. 1978;14(9):1620 1624. (in Russian)]

Кутузова С.Н., Брач Н.Б., Пороховинова Е.А., Низова Н.К., Шаров И.Я., Крат Т.Е., Логинова Л.А., Жученко А.А., Лошакова Н.И., Рожми на Т.А., Курчакова Л.П., Крылова Т.В., Александрова Т.А., Кудрявцева Л.И., Никандрова М.Л., Рысева Т.А. Каталог мировой коллекции ВИР. Вып. 714. Доноры хозяйственно ценных признаков для селекции льна долгунца. СПб: Изд-во ВИР, 2000.

[KutuzovaS.N.,BrutchN.B.,PorokhovinovaE.A.,NizovaN.K.,Sharovl.Ya., KratT.A., Loginova L.A., Zhuchenko A.A., Loshakova N.I., RozhminaT.A., Kurchakova L.P., Krylova T.V., Aleksandrova T.A., Kudryavtceva L.I., Nicandrova M.L., Ryseva T.A. Catalog of VIR world collection. Issue 714. Donors of agronomical valuable characters for fiber flax breeding. St. Petersburg: VIR, 2000. (in Russian)]

Кутузова С.Н., Брач Н.Б., Пороховинова Е.А., Павлов А.В. Исходный материал льна-долгунца в коллекции ФГБНУ ФИЦ ВНИИР и его использование в селекции. В: Научное обеспечение производства прядильных культур: состояние, проблемы и перспективы. Сборник научных трудов. Тверь, 2018;81-87.
[Kutuzova S.N., Brutch N.B., Porokhovinova E.A., Pavlov A.V. Initial material of fiber flax in VIR collection and its utilization in breeding. In: Scientific support for the production of fiber crops: state, problems and prospects. Tver, 2018;81-87. (in Russian)]

Кутузова С.Н., Брач Н.Б., Пороховинова Е.А., Павлов А.В., Шаров И.Я Проблемы селекции льна-долгунца и исходный материал для их решения в коллекции ВИР. В: Научные достижения - льноводству. Материалы научно-практической конференции «Основные результаты и направления развития научных исследований по льну-долгунцу», посвященной 80-летию образованию ВНИИ льна. 2010;29-35.

[Kutuzova S.N., Brutch N.B.,Porokhovinova E.A.,Pavlov A.V.,SharovI.Ya. Problems of fiber flax breeding and the initial material for their solution in VIR collection. In: Scientific achivements for flax production. Proceedings of scientific practical conference "The main results and directions of development of scientific research on flax", dedicated to the 80th anniversary of the Flax Research Institute foundation. 2010;29-35. (in Russian)]

Кутузова С.Н., Брач Н.Б., Пороховинова Е.А., Шаров И.Я., Павлов А.В. Сравнительная характеристика сортов льна-долгунца, районированных с 1932 по 2000 гг. В: Проблемы повышения технологического качества льна-долгунца. Материалы Международной научно-технической конференции. 2005;40-48.

[Kutuzova S.N., Brutch N.B., Porokhovinova E.A., Sharovl.Ya.,Pavlov A.V. Comparative characteristics of fiber flax varieties delivered in 1932 2000. In: Problems of fiber flax technological quality improvement. Proceedings of international scientific conference 2005;40-48. (in Russian)]

Кутузова С.Н., Брач Н.Б., Тихвинский С.Ф., Доронин С.В., Шаров И.Я., Питько А.Г. Географическая изменчивость хозяйственно ценных признаков льна. Труды по прикладной ботанике, генетике и селекции. 1991a;144:40-48.

[Kutuzova S.N., Brach N.B., Tikhvinskiy S.F., Doronin S.V., Sharov I.Ya., Pit'ko A.G. Geographical variability of economically valuable characters in flax. Proceedings on Applied Botany, Genetics and Breeding. 1991a;144:40-48. (in Russian)]

Кутузова С.Н., Куликова А.Е., Брач Н.Б., Рыкова Р.П. и др. Каталог мировой коллекции ВИР. Вып. 582. Лен-долгунец (Характеристика образцов по комплексу хозяйственно ценных признаков). Л.: Изд-во ВИР, 19916.

[Kutuzova S.N., Kulikova A.E., Brutch N.B., Rykova R.P. et. al. Catalog of VIR world collection. Issue 582. Fiber flax (Accessions characteristics according to the complex of economically valuable traits. Leningrad: VIR, 1991b. (in Russian)]

Кутузова С.Н., Питько А.Г. Изучение коллекции льна (Linum usitaissimum L.). Методические указания. Л.: Изд-во ВИР, 1988.

[Kutuzova S.N., Pit'ko A.G. Evaluation of flax (Linum usitaissimum L.) collection. Methodological guidelines. Leningrad: VIR, 1988. (in Russian)]

Кутузова С.Н., Пороховинова Е.А., Брач Н.Б., Павлов А.В. Мировой генофонд льна-долгунца ВИР и селекция устойчивых к ржавчине сортов. Труды по прикладной ботанике, генетике и селекции. 2020;181(2):57-64. DOI 10.30901/2227-8834-2020-2-57-64.

[Kutuzova S.N., Porokhovinova E.A., Brutch N.B., Pavlov A.V. Worldwide gene pool of fiber flax at VIR and breeding of rust-resistant varieties. Proceedings on Applied Botany, Genetics and Breeding. 2020;181(2):57-64. DOI 10.30901/2227-8834-2020-2-57-64. (in Russian)]

Кутузова С.Н., Пороховинова Е.А., Пендинен Г.И. Происхождение и эволюция вида Linum usitatissimum L. Tруды по прикладной ботанике, генетике и селекции. 2015;176:107-117. DOI 10.30901/2227-8834-2015-4-436-455.

[Kutuzova S.N., Porokhovinova E.A., Pendinen G.I. Origin and evolution of Linum usitaissimum L. Proceedings on Applied Botany, Genetics and Breeding. 2015;176:107-117. DOI 10.30901/2227-8834-2015-4436-455. (in Russian)]

Кутузова С.Н., Санин А.А., Косых Л.А. Источники устойчивости к засухе в коллекции льна для селекции льна масличного. Труды по прикладной ботанике, генетике и селекции. 2009;166:534-540. [Kutuzova S.N., Sanin A.A., Kosykh L.A. Source of drought resistance in flax collection VIR for selection of linseed. Proceedings on Applied Botany, Genetics and Breeding. 2009;166:534-540. (in Russian)] 
Лукомец В.М., Зеленцов С.В., Кривошлыков К.М. Перспективы и резервы расширения производства масличных культур в Российской Федерации. Масличные культуры. Научно-технический бюллетень Всероссийского научно-исследовательского института масличных культур. 2015;4(164):81-102.

[Lukomets V.M., Zelentsov S.V., Krivoshlykov K.M. Outlook and reserves the expansion of oil crops production in the Russian Federation. Oil crops. Scientific and Technical Bulletin of VNIIMK. 2015;4(164):81-102. (in Russian)]

Лебедев А.Д., Эверт А.Ф. Географическое распределение льноводных регионов СССР по качеству волокна в связи с температурой и осадками вегетационного периода. Труды по прикладной бота нике, генетике и селекции. 1928;18(1):371-396.

[Lebedev A.D., Evert A.F. Geographical distribution of flax-growing regions of the USSR by fiber quality in connection with temperature and precipitation of the growing season. Proceedings on Applied Bot any, Genetics and Breeding. 1928;18(1):371-396. (in Russian)]

Мамедова С.М., Вишнякова М.А. Генетическое разнообразие коллекции бобов (Vicia faba) ВИР и его использование в селекции. Труды по прикладной ботанике, генетике и селекции. 2020;181(3):181189. DOI 10.30901/2227-8834-2020-3-181-189.

[Mamedova S.M., Vishnyakova M.A. Genetic diversity of broad beans (Vicia faba) in the collection of the Vavilov Institute and its use in breeding. Proceedings on Applied Botany, Genetics and Breeding. 2020;181(3):181-189. DOI 10.30901/2227-8834-2020-3-181-189. (in Russian)]

Низова Г.К., Кутузова С.Н., Ярош Н.П., Жаворонкова А.А., Калуги на А.Ф., Брач Н.Б., Пороховинова Е.А., Питько Г.Г. Каталог мировой коллекции ВИР. Вып. 775. Лен (характеристика образцов по биохимическим признакам). СПб: Изд-во ВИР, 2006.

[Nizova G.K., Kutuzova S.N., Yarosh N.P., Zhavoronkova A.A., Kalugina A.F., Brutch N.B., Porokhovinova E.A., Pit'ko G.G. Catalog of VIR world collection. Issue 775. Flax (accessions biochemical characteristics). St. Petersburg: VIR, 2006. (in Russian)]

Новикова Л.Ю., Дюбин В.Н., Лоскутов И.Г., Зуев Е.В., Ковалева О.Н., Пороховинова Е.А., Сеферова И.В., Булынцев С.В., Артемьева А.М., Киру С.Д., Рогозина Е.В., Наумова Л.Г. Анализ динамики хозяйственно-ценных признаков сортов сельскохозяйственных культур в условиях изменения климата. Труды по прикладной ботанике, генетике и селекции. 2013;173:102-119.

[Novikova L.YU.,Dyubin V.N.,LoskutovI.G., ZuevE.V., Kovaleva O.N.,Porokhovinova E.A., Seferova I.V., Bulyntsev S.V., Artemieva A.M., Kiru S.D., Rogozina E.V., Naumova L.G. Analysis of economical valuable characters of cereals cultivars under climate change conditions. Proceedings on Applied Botany, Genetics and Breeding. 2013;173:102-119. (in Russian)]

Павлов А.В., Кутузова С.Н., Брач Н.Б., Пороховинова Е.А., Шаров И.Я. Анализ коллекции льна-долгунца ВИР для решения проблемы селекции на повышение качества волокна. Доклады Российской академии сельскохозяйственных наук. 2007;3:16-19.

[Pavlov A.V., Kutuzova S.N., Brutch N.B., Porokhovinova E.A., Sharovl.Ya. Analysis of the VIR fiber flax collection to solve the problem of breeding for improvement of fiber quality. Reports of the Russian Academy of Agricultural Sciences. 2007;3:16-19. (in Russian)]

Павлов А.В., Пороховинова Е.А., Щербаков А.В. Влияние биологических препаратов на урожайность и качество волокна льна-долгунца. В: 125 лет прикладной ботаники В России. Сборник тезисов. Министерство науки и высшего образования РФ, Федеральный исследовательский центр Всероссийский институт генетических ресурсов растений им. Н.И. Вавилова, 2019;173.

[Pavlov A.V., Porokhovinova E.A., Sherbakov A.V. The effect of biolog ical preparations on the yield and quality of flax fiber. Proceedings of the conference 125 years of applied botany in Russia. VIR, 2019;173. (in Russian)]

Питько Г.Г., Кутузова С.Н., Рыкова Р.П., Брач Н.Б., Мусорина Л.И. Каталог мировой коллекции ВИР. Вып. 664. Лен масличный (Характеристика образцов по комплексу хозяйственно ценных признаков). СПб: Изд-во ВИР, 1994.

[Pit'ko G.G., Kutuzova S.N., Rykova R.P., Brutch N.B., Musorina L.I. Catalog of VIR world collection. Issue 664. Linseed (Characteristics of accessions according to the complex of economically valuable characters). St. Petersburg: VIR, 1994. (in Russian)]
Попова Г.А., Мичкина Г.А., Рогальская Н.Б., Трофимова В.М., Брач Н.Б Использование мировых генетических ресурсов льна коллекции ВИР в создании сортов томской селекции. Труды по прикладной ботанике, генетике и селекции. 2015;176(1):76-87. DOI 10.30901/2227-8834-2015-1-76-87.

[Popova G.A., Michkina G.A., Rogalskaya N.B., Trofimova V.M., Brach N.B. Involvement of worldwide flax genetic resources from VIR's collection in the development of cultivars in Tomsk. Proceedings on Applied Botany, Genetics and Breeding. 2015;176(1):76-87. DOI 10.30901/2227-8834-2015-1-76-87. (in Russian)]

Пороховинова Е.А. Генетический контроль восстановления фертильности пыльцы у линий льна (Linum usitatissimum L.) с цитоплазматической мужской стерильностью. Труды по прикладной ботанике, генетике и селекции. 2017;178(1):68-81. DOI 10.30901/2227-8834-2017-1-68-81.

[Porokhovinova E.A. Genetic control of fertility restoration in CMS lines of flax (Linum usitatissimum L.). Proceedings on Applied Botany, Genetics and Breeding. 2017;178(1):68-81. DOI 10.30901/2227-88342017-1-68-81. (in Russian)]

Пороховинова Е.А., Шеленга Т.В., Косых Л.А., Санин А.А., Казарина А.В., Кутузова С.Н., Павлов А.В., Брач Н.Б. Биохимическое разнообразие льна по жирнокислотному составу семян в генетической коллекции ВИР и влияние условий среды на его проявление. Экологическая генетика. 2016;14(1):13-26. DOI 10.17816/ecogen14113-26. [Porokhovinova E.A., Shelenga T.V., Kosykh L.A., Sanin A.A., Kazarina A.V., Kutuzova S.N., Pavlov A.V., Brach N.B. Biochemical diversity of fatty acid composition in flax from VIR's genetic collection and effect of environment on its development. Russian Journal of Genetics: Applied Research. 2017;7(6):626-639.DOI 10.1134/S2079059717060107]

Пороховинова Е.А., Павлов А.В., Кутузова С.Н., Брач Н.Б. Взаимодействие генов, контролирующих некоторые морфологические признаки льна (Linum usitatissimum L.). Генетика. 2019а;55(11):13351349. DOI 10.1134/S0016675819110109.

[Porokhovinova E.A., Pavlov A.V., Kutuzova S.N., Brutch N.B. Interaction of genes controlling some morphological features of flax (Linum usitatissimum L.). Russian Journal of Genetics. 2019a;55(11):13831397. DOI 10.1134/S0016675819110109]

Пороховинова Е.А., Кутузова С.Н., Павлов А.В., Бузовкина И.С., Брач Н.Б. Разнообразие морфологических признаков льна в генетической коллекции ВИР как результат его доместикации. Экологическая генетика. 2018;16(4):33-50.

[Porokhovinova E.A., Kutuzova S.N., Pavlov A.V., Buzovkina I.S., Brutch N.B. Diversity of flax morphological characters in VIR genetic collection as a result of crop domestication. Ecological Genetics. 2018;16(4):33-50. DOI 10.17816/ecogen16433-50. (in Russian)]

Пороховинова Е.А., Павлов А.В., Брач Н.Б., Морван К. Углеводный состав слизи из семян льна и его связь с морфологическими признаками. Сельскохозяйственная биология. 2017;52(1):161171. DOI 10.15389/agrobiology.2017.1.161rus.

[Porokhovinova E.A., Pavlov A.V., Brach N.B., Morvan C. Carbohydrate composition of flax mucilage and its relation to morphological characters. Sel'skokhozyaistvennaya Biologiya = Agricultural Biology. 2017;52(1):161-171. DOI 10.15389/agrobiology.2017.1.161eng]

Пороховинова Е.А., Морван К., Брач Н.Б., Кутузова С.Н. Генетическая коллекция льна в ВИРе: фундаментальное и прикладное использование. Труды по прикладной ботанике, генетике и селекции. 2013;174:107-116. DOI 10.17816/ecogen14113-26.

[Porokhovinova E.A., Morvan C., Brutch N.B., Kutuzova S.N. VIR flax genetic collection: fundamental and applied use. Proceedings on Applied Botany, Genetics and Breeding. 2013;174:107-116. DOI 10.17816/ ecogen14113-26. (in Russian)]

Пороховинова Е.А., Шеленга Т.В., Матвеева Т.В., Павлов А.В., Григорьева Е.А., Брач Н.Б. Полиморфизм генов, контролирующих низкое содержание линоленовой кислоты, у линий генетической коллекции льна ВИР. Экологическая генетика. 20196;17(2):5-19. DOI 10.17816/ ecogen1725-19.

[Porokhovinova E.A., Shelenga T.V., Matveeva T.V., Pavlov A.V., Grigorieva E.A., Brutch N.B. Polymorphism of genes controlling low level of linolenic acid in lines from VIR flax genetic collection. Ecological Genetics. 2019b;17(2):5-19. DOI 10.17816/ecogen1725-19]

Рыкова Р.П. Источники цитоплазматической мужской стерильности льна. Труды по прикладной ботанике, генетике и селекции. 1979;64(2):52-58. 
[Rykova R.P. The sources of cytoplasmic male sterility in flax. Proceed ings on Applied Botany, Genetics and Breeding. 1979;64(2):52-58. (in Russian)]

Сизов И.А., Гращенко М.Г., Рыкова Р.П. Каталог мировой коллекции ВИР. Выпуск 40. Лен-долгунец. Л.: Изд-во ВИР, 1968.

[Sizov I.A., Grashenko M.G., Rykova R.P. Catalog of VIR world collec tion. Issue 40. Fiber flax. Leningrad: VIR, 1968. (in Russian)]

Сизов И.А. Лен. М.-Л.: Сельхозгиз, 1955;256.

[Sizov I.A. Linum. Moscow - Leningrad: Selhosgiz Publ., 1955;256. (in Russian)]

Сизова М.A. Динамика образования лубоволокнистых пучков в стебле различных сортов льна в зависимости от условий выращивания. Труды по прикладной ботанике, генетике и селекции. 1952;29(2):52-61.

[Sizova M.A. Dynamics of the bast fiber bundles formation in the stem of various flax varieties, depending on the growing conditions. Proceedings on Applied Botany, Genetics and Breeding. 1952;29(2):52 61. (in Russian)]

Синская Е.Н. Классификация льна как исходного материала для селекции и его эволюция В: Сборник работ биологии развития и физиологии льна. М.: Сельхозгиз, 1954;45-102.

[Sinskaya E.N. Classification of flax as source material for breeding and its evolution. In: Collection of works on flax biology and physiology. Moscow: Selhosgiz Publ.,1954;45-102. (in Russian)]

Чернова Т.Е., Гурьянов О.П., Брач Н.Б., Павлов А.В., Пороховинова Е.А., Кутузова С.Н., Чемикосова С.Б., Горшкова Т.А. Вариабельность состава тканеспецифичного галактана волокон льна. Физиология растений. 2007;54(6):876-884.

[Chernova T.E., Gur'yanov O.P., Chemikosova S.B., Gorshkova T.A., Brach N.B., Pavlov A.V., Porokhovinova E.A., Kutuzova S.N. Variability in the composition of tissue-specific galactan from flax fibers. Russian Journal of Plant Physiology. 2007;54(6):782-789. DOI 10.1134/ S1021443707060106]
Эллади Е.B. Linum usitaissimum L. consp. Tov. Лен. B: Культурная флора СССР. М.-Л.: 1940;5:109-208.

[Elladi E.V. Linum usitatissimum L. consp. nov. Flax. In: Flora of cultivated plants. Moscow - Leningrad: 1940;5:109-208. (in Russian)]

Brach N.B., Matvienko I., Porokhovinova E., Pavlov A., Nozkova J., Koshkin V. Effect of photoperiod on Linum usitaissimum L. characters. Journal of Natural Fibers. 2020;17(9):1345-1354. DOI 10.1080/15440478.2019.1568345.

Brutch N.B., Porokhovinova E.A., Sharov I.Y., Soret-Morvan O., Morvan C. Characters of fibre quality in lines of flax genetic collection. Journal of Natural Fibers. 2008;5(2):95-126. DOI 10.1080/15440470801928939.

Kutuzova S.N., Porokhovinova E.A., Brutch N.B., Pavlov A.V. Localization of rust resistance genes in old local Russian flaxes by methods of classical genetics. Vavilovskii Zhurnal Genetiki i Selektsi = Vavilov Journal of Genetics and Breeding. 2019;23(6):650-655. DOI 10.18699/ VJ19.537.

Nozkova Ja., Pavelek M., Bjelkova M., Brutch N., Tejklova E., Porokhovinova E., Brindza J. Descriptor list for flax (Linum usitaissimum L.). Nitra, 2016

Pavlov A., Paynel F., Rihouey C., Porokhovinova E., Brutch N., Morvan C. Variability of seed traits and properties of soluble mucilages in lines of the flax genetic collection of Vavilov institute. Plant Physiol. Biochem. 2014;80:348-361. DOI 10.1016/j.plaphy.2014.04.020.

Pavlov A., Matvienko I., Brutch N., Nozkova J., Savrtkova M. Photoperiod influence on the stem structure of fibre flax. Agriculture (Polnohospodárstvo). 2018;64(4):160-172. DOI 10.2478/agri-2018-0017.

Wang Z., Hobson N., Galindo L., Zhu S., Shi D., McDill J., Yang, L., Hawkins S., Neutelings G., Datla R., Lambert G., Galbraith D. W., Grassa C. J., Geraldes A., Cronk Q. C., Cullis C., Dash P. K., Kumar P.A., Cloutier S., Sharpe A. G., Wong G.K.-S., Wang J., Deyholos M.K. The genome of flax (Linum usitatissimum) assembled de novo from short shotgun sequence reads. Plant J. 2012;72:461-473. DOI 10.1111/j.1365313X.2012.05093.x.

Конфликт интересов. Авторы заявляют об отсутствии конфликта интересов.

Поступила в редакцию 26.04.2021. После доработки 17.05.2021. Принята к публикации 20.05.2021. 